\title{
PENERAPAN STRATEGI EKSPOSITORI UNTUK MENINGKATKAN PENGETAHUAN SISWA TENTANG PELUANG KEJADIAN MAJEMUK
}

\author{
Totong Budiarto \\ SMA Negeri 1 Kawali, Jl. Poronggol Raya No.9, Kawali, Ciamis, Indonesia \\ Email: tonxbudhi@gmail.com
}

\begin{abstract}
A classroom action research has been carried out in class XII IPA 6 SMA Negeri 1 Kawali in the academic year of 2018/2019, implementating expository learning strategy in mathematics on the subject matter of multiple event opportunities. This classroom action research takes place in two cycles each of which consists of 4 stages, namely, planning, implementing actions, observing and reflecting. The subjects are 35 students of class XII IPA 6 SMA Negeri 1 Kawali in the academic year of 2018/2019. The data are collected through observation and tests. The data are analysed qualitatively consistsing of three main stages, namely, data reduction, data exposure and drawing conclusion. The results of this study shows that the expository strategy can increases knowledge of the chance of multiple incidents in class XII IPA 6 SMA Negeri 1 Kawali in the academic year of 2018/2019. This is indicated by the fact that changes in teacher performance and student learning skills are more positive towards learning. In addition, there was an increase in percentage of material mastery with average value of 20.0\%; and an increase in learning completeness with the percentage of $88.6 \%$. Furthermore, after getting action through expository strategies, students in class XII IPA 6 have more positive suggestions for learning, understand the learning objectives that must be achieved, have curiosity towards the material, concentrate, are enthusiastic, think critically, and are serious in learning.
\end{abstract}

Keywords: Expository Strategy, Student Knowledge, Multiple Event Opportunities

\begin{abstract}
ABSTRAK
Sebuah penelitian tindakan kelas telah dilaksanakan di kelas XII IPA 6 SMA Negeri 1 Kawali tahun pelajaran 2018/2019 dengan topik penerapan strategi pembelajaran ekspositori dalam mata pelajaran matematika pada pokok materi peluang kejadian majemuk. Penelitian tindakan kelas ini berlangsung dalam dua siklus masing-masing terdiri dari 4 tahapan yaitu perencanaan, pelaksanaan tindakan, observasi dan refleksi. Subyek penelitian adalah 35 siswa kelas XII IPA 6 SMA Negeri 1 Kawali tahun pelajaran 2018/2019. Pengumpulan data diperoleh dari observasi dan tes. Sedangkan teknik analisis data diolah secara kualitatif yang terdiri dari tiga tahap pokok, yaitu reduksi data, paparan data dan penarikan kesimpulan. Hasil penelitian ini menunjukkan bahwa strategi ekspositori dapat meningkatkan pengetahuan tentang peluang kejadian majemuk siswa kelas XII IPA 6 SMA Negeri 1 Kawali tahun pelajaran 2018/2019. Hal ini ditandai dengan adanya perubahan kinerja guru dan keterampilan belajar siswa menjadi lebih positif terhadap pembelajaran. Selain itu, adanya peningkatan dalam persentase penguasaan materi dengan nilai rata-rata sebesar $20.0 \%$ dan peningkatan ketuntasan belajar sebesar $88.6 \%$. Selain itu, setelah mendapatkan tindakan melalui strategi ekspositori, siswa kelas XII IPA 6 lebih memiliki sugesti positif terhadap pembelajaran, memahami tujuan pembelajaran yang harus dicapai, memiliki keingintahuan terhadap materi, konsentrasi, antusias, berpikir kritis, dan bersungguh-sungguh dalam belajar.
\end{abstract}

Kata Kunci: Strategi Ekspositori, Pengetahuan Siswa, Peluang Kejadian Majemuk

Cara sitasi: Budiarto, T. (2020). Penerapan Strategi Ekspositori untuk Meningkatkan Pengetahuan Siswa tentang Peluang Kejadian Majemuk. J-KIP (Jurnal Keguruan dan IImu Pendidikan) , 1 (2), 47-54. 


\section{PENDAHULUAN}

Matematika adalah bahasa universal untuk menyajikan gagasan atau pengetahuan secara formal dan presisi sehingga tidak memungkinkan terjadinya multi tafsir. Penyampaiannya adalah dengan membawa gagasan dan pengetahuan konkret ke bentuk abstrak melalui pendefinisian variabel dan parameter sesuai dengan yang ingin disajikan. Penyajian dalam bentuk abstrak melalui matematika akan mempermudah analisis dan evaluasi selanjutnya.

Permasalahan terkait gagasan dan pengetahuan yang disampaikan secara matematis akan dapat diselesaikan dengan prosedur formal matematika yang langkahnya sangat presisi dan tidak terbantahkan. Karenanya matematika berperan sebagai alat komunikasi formal paling efisien. Perlu kemampuan berpikir kritis-kreatif untuk menggunakan matematika seperti yang telah diuraikan: menentukan variabel dan parameter, mencari keterkaitan antar variabel dan dengan parameter, membuat dan membuktikan rumusan matematika suatu gagasan, membuktikan kesetaraan antar beberapa rumusan matematika, menyelesaikan model abstrak yang terbentuk, dan mengkonkretkan nilai abstrak yang diperoleh.

Dalam silabus Kurikulum 2013 untuk mata pelajaran matematika di kelas XII IPA semester genap di SMA Negeri 1 Kawali tahun pelajaran 2018/2019 terdapat kompetensi dasar nomor 3.5, yaitu "Mendeskripsikan dan menentukan peluang kejadian majemuk (peluang kejadian-kejadian saling bebas, saling lepas, dan kejadian bersyarat) dari suatu percobaan acak". Kompetensi dasar tersebut dapat dijabarkan menjadi indikator-indikator sebagai tujuan pembelajaran. Beberapa di antaranya adalah 1) Memahami peluang kejadian majemuk; 2) Mengetahui kejadian saling bebas; 3) Mengetahui kejadian saling lepas ; 4) Mengetahui peluang kejadian bersyarat.

Berdasarkan hasil observasi di awal penelitian, pembelajaran tentang peluang kejadian majemuk di kelas XII IPA 6 SMA Negeri 1 Kawali tahun pelajaran 2018/2019 masih jauh dari harapan. Hasil observasi terhadap proses pembelajaran sehari-hari menyatakan bahwa guru masih menggunakan metode konvensional. Materi peluang kejadian majemuk disampaikan dengan menggunakan metode konvensional yang menjemukan dan monoton. Guru hanya memberikan sedikit kesempatan kepada siswa untuk menguatkan pengetahuan mereka tentang materi ini.

Kinerja guru berdampak kepada keterampilan belajar siswa kelas XII IPA 6 ketika pembelajaran berlangsung. Peneliti dan observer melihat beberapa siswa hilang konsentrasi dan melakukan kegiatan lain yang tidak ada hubungannya dengan pelajaran, seperti bermain-main dengan teman, melamun, terkadang menulis sesuatu yang tidak ada hubungannya dengan pelajaran. Dari 35 orang siswa yang ada di kelas ini, hanya $\leq 25 \%$ saja yang memiliki sugesti positif terhadap pembelajaran, memahami tujuan pembelajaran yang harus dicapai, memiliki keingintahuan terhadap materi, konsentrasi dalam menyimak penjelasan, antusias dalam merespons joke-joke, berusaha berpikir kritis dalam menghubungkan materi dengan pengalaman sehari-hari, dan bersungguhsungguh dalam menyimak kesimpulan materi.

Dalam sesi tes awal, terlihat siswa begitu kebingungan dengan apa yang diberikan guru kepada mereka. Sebagian dari mereka berusaha menyontek hasil kerja siswa lain sehingga suasana kelas terlihat sangat tidak teratur. Menurut data hasil tes di awal penelitian, siswa kelas XII IPA 6 tidak dapat mencapai tujuan pembelajaran dengan maksimal. Dari hasil tes awal dapat diketahui sebagian besar siswa kelas XII IPA 6 mendapat nilai $<75$. Jumlah siswa yang mendapat $\geq 75$ hanya 4 orang. Sedangkan jumlah siswa yang mendapat $<75$ adalah 31 orang. Dari hasil tes awal ini didapatkan data yang tidak memuaskan, tampak bahwa ketuntasan belajar hanya mencapai $11.4 \%$ dengan tingkat penguasaan materi hanya sebesar $67.1 \%$ saja.

Berdasarkan data awal yang terkumpul peneliti menyimpulkan bahwa siswa kelas XII IPA 6 kesulitan untuk dapat menguasai kompetensi tentang peluang kejadian majemuk ini. Beberapa siswa mengemukakan alasan karena materi ini sangat banyak sehingga susah untuk dikuasai.

Peneliti dibantu kedua orang observer berusaha mencari solusi untuk bagaimana supaya siswa mampu menguasai materi tentang peluang kejadian majemuk dengan baik. Peneliti 
memutuskan untuk memakai strategi pembelajaran ekspositori. Dengan memakai strategi ini, guru dapat meningkatkan kualitas proses pembelajaran dengan memberikan sugesti yang positif, mengemukakan tujuan pembelajaran yang harus dicapai, merangsang keingintahuan siswa terhadap materi, menggunakan bahasa yang komunikatif dan mudah dipahami, menggunakan intonasi suara sesuai dengan pesan yang ingin disampaikan, melakukan kontak mata dengan siswa, menggunakan joke-joke yang menyegarkan, menghubungkan materi pelajaran dengan pengalaman siswa seharihari, dan menyimpulkan materi.

Langkah-langkah pembelajaran tentang peluang kejadian majemuk melalui strategi ekspositori diharapkan dapat lebih meningkatkan keterampilan belajar mereka. Sehingga siswa kelas XII IPA 6 diharapkan dapat memiliki sugesti positif terhadap pembelajaran, memahami tujuan pembelajaran yang harus dicapai, memiliki keingintahuan terhadap materi, lebih konsentrasi, antusias, berusaha berpikir kritis, dan bersungguh-sungguh dalam belajar. Dengan menggunakan strategi ekspositori, diharapkan siswa kelas XII IPA 6 dapat lebih mudah menguasai materi tentang peluang kejadian majemuk.

Berdasarkan latar belakang yang telah dipaparkan, maka penulis tertarik untuk melaksanakan penelitian tindakan kelas dengan judul "Penerapan Strategi Ekspositori Untuk Meningkatkan Pengetahuan Siswa Tentang Peluang Kejadian Majemuk". Penulis memiliki hipotesis yaitu Strategi ekspositori dapat meningkatkan pengetahuan siswa kelas XII IPA 6 SMA Negeri 1 Kawali tahun pelajaran 2018/2019 tentang peluang kejadian majemuk.

\section{METODE PENELITIAN}

Penelitian tindakan kelas ini dilaksanakan di SMA Negeri 1 Kawali pada tahun pelajaran 2018/2019 semester genap, yaitu dimulai pada tanggal 07 Januari 2019 sampai dengan tanggal 03 Juni 2019 dengan subyek penelitiannya adalah siswa-siswi kelas XII IPA 6 SMA Negeri 1 Kawali tahun pelajaran 2018/2019 yang berjumlah 35 orang.

Penelitian ini merupakan proses pengkajian sistem berdaur. Prosedur penelitian mencakup tahapan-tahapan sebagai berikut: a) perencanaan (planning); b) tindakan (action); c) observasi dan evaluasi proses dan hasil tindakan (observation and evaluation); dan d) melakukan refleksi (reflecting) dan seterusnya sampai perbaikan atau peningkatan yang diharapkan tercapai. Metode pengumpulan data penelitian ini menggunakan observasi dan tes.

Data yang diperoleh dari penelitian dianalisis untuk mengetahui apakah penggunaan strategi ekspositori dapat meningkatkan pengetahuan tentang peluang siswa kelas XII IPA 6 atau tidak. Data hasil observasi dianalisis secara kualitatif. Teknik analisis data terdiri dari tiga tahap pokok, yaitu reduksi data, paparan data dan penarikan kesimpulan. Sedangkan data kuantitatif dianalisa dengan menggunakan analisis deskriptif dan sajian visual.

Penelitian ini dikatakan berhasil apabila:

1. Hasil tes menunjukkan bahwa semua siswa kelas XII IPA 6 mendapat nilai $\geq 75$ (ketuntasan belajar mencapai $100 \%$ ).

2. Hasil observasi terhadap kinerja guru menunjukkan bahwa kinerja guru minimal dalam kategori baik.

3. Hasil observasi terhadap keterampilan belajar siswa menunjukkan bahwa keterampilan belajar siswa kelas XII IPA 6 minimal dalam kategori baik. 


\section{HASIL DAN PEMBAHASAN}

Data yang diperoleh dari hasil penelitian ini disajikan Tabel 1.

Tabel 1. Hasil Analisis terhadap Kinerja Guru

\begin{tabular}{llll}
\hline \multicolumn{1}{c}{ Kriteria } & \multicolumn{1}{c}{ Pra Siklus } & \multicolumn{1}{c}{ Siklus 1 } & \multicolumn{1}{c}{ Siklus 2 } \\
\hline Jumlah skor & 12 & 21 & 30 \\
Rata-rata skor & 1.33 & 2.33 & 3.33 \\
Kategori & Kurang & Cukup & Sangat Baik \\
\hline
\end{tabular}

Data hasil penelitian pada Tabel 1 juga disajikan dalam bentuk histogram yang disajikan pada Gambar 1.

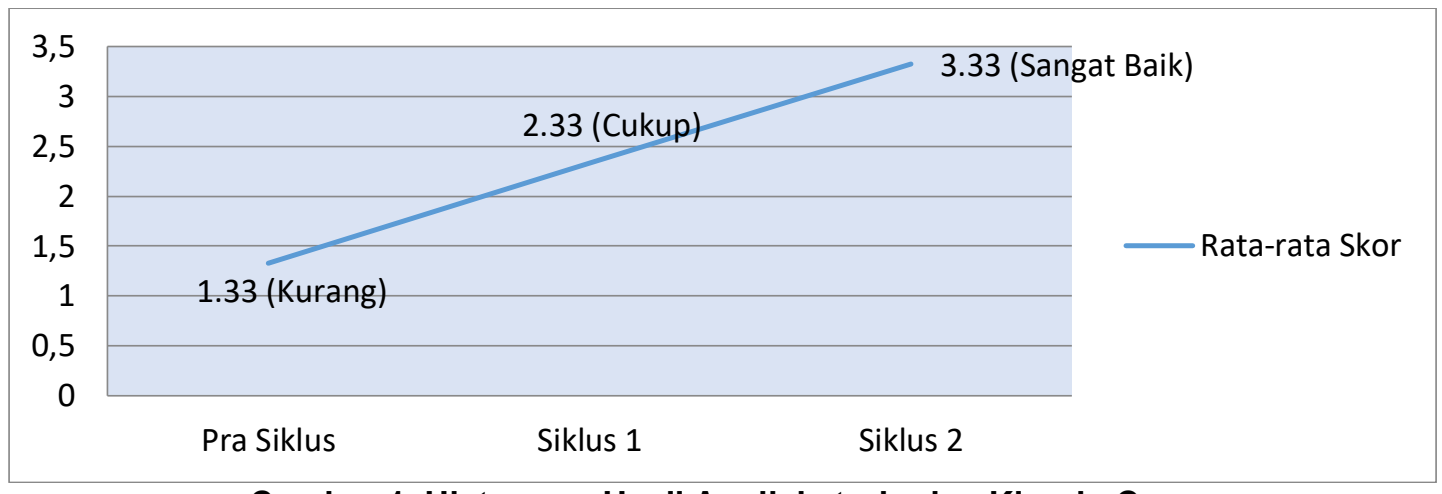

Gambar 1. Histogram Hasil Analisis terhadap Kinerja Guru

Dari Tabel 1 dapat diketahui bahwa ada peningkatan pada kinerja guru. Pada tindakan pra siklus rata-rata skor kinerja guru adalah 1.33 (kategori kurang). Di akhir siklus 2, rata-rata skor kinerja guru meningkat menjadi 3.33 (kategori sangat baik). Ini berarti bahwa indikator keberhasilan untuk kinerja guru telah tercapai. Tabel 2.

Data penelitian mengenai hasil analisis terhadap keterampilan belajar siswa disajikan pada

Tabel 2. Hasil Analisis terhadap Keterampilan Belajar Siswa

\begin{tabular}{llll}
\hline \multicolumn{1}{c}{ Kriteria } & \multicolumn{1}{c}{ Pra Siklus } & \multicolumn{1}{c}{ Siklus 1 } & \multicolumn{1}{c}{ Siklus 2 } \\
\hline Jumlah skor & 7 & 14 & 21 \\
Rata-rata skor & 1.00 & 2.00 & 3.00 \\
Kategori & Kurang & Cukup & Baik \\
\hline
\end{tabular}

Data hasil penelitian pada Tabel 2 juga disajikan dalam bentuk histogram yang disajikan pada Gambar 2.

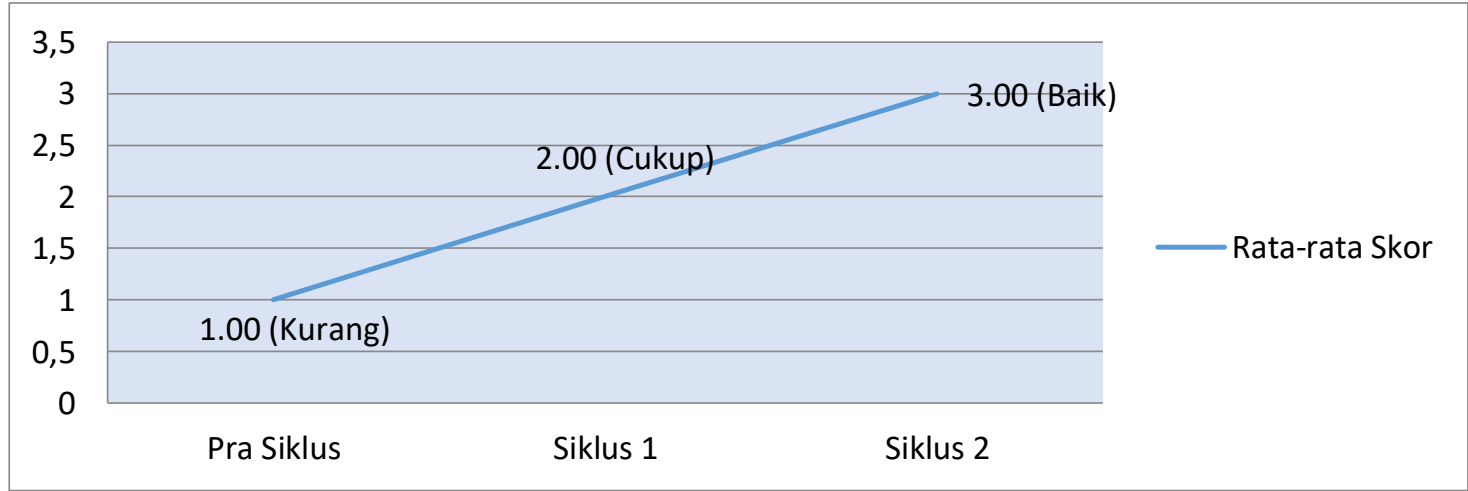

Gambar 2. Histogram Hasil Analisis terhadap Keterampilan Belajar Siswa 
Dari Tabel 2 dapat diketahui bahwa ada peningkatan pada keterampilan belajar siswa kelas XII IPA 6. Pada tindakan pra siklus rata-rata skor keterampilan belajar siswa adalah 1.00 (kategori kurang). Di akhir siklus 2, rata-rata skor keterampilan belajar siswa meningkat menjadi 3.00 (kategori baik). Ini berarti bahwa indikator keberhasilan untuk keterampilan belajar siswa telah tercapai.

Data penelitian mengenai hasil analisis terhadap nilai tes disajikan pada Tabel 3.

Tabel 3. Hasil Analisis terhadap Nilai Tes

\begin{tabular}{lccc}
\hline \multicolumn{1}{c}{ Kriteria } & Pra Siklus & Siklus 1 & Siklus 2 \\
\hline Tingkat Penguasaan Materi & $67.1 \%$ & $77.1 \%$ & $87.1 \%$ \\
Ketuntasan Belajar & $11.4 \%$ & $60.0 \%$ & $100 \%$ \\
\hline
\end{tabular}

Data hasil penelitian pada Tabel 3 juga disajikan dalam bentuk histogram yang disajikan pada Gambar 3.

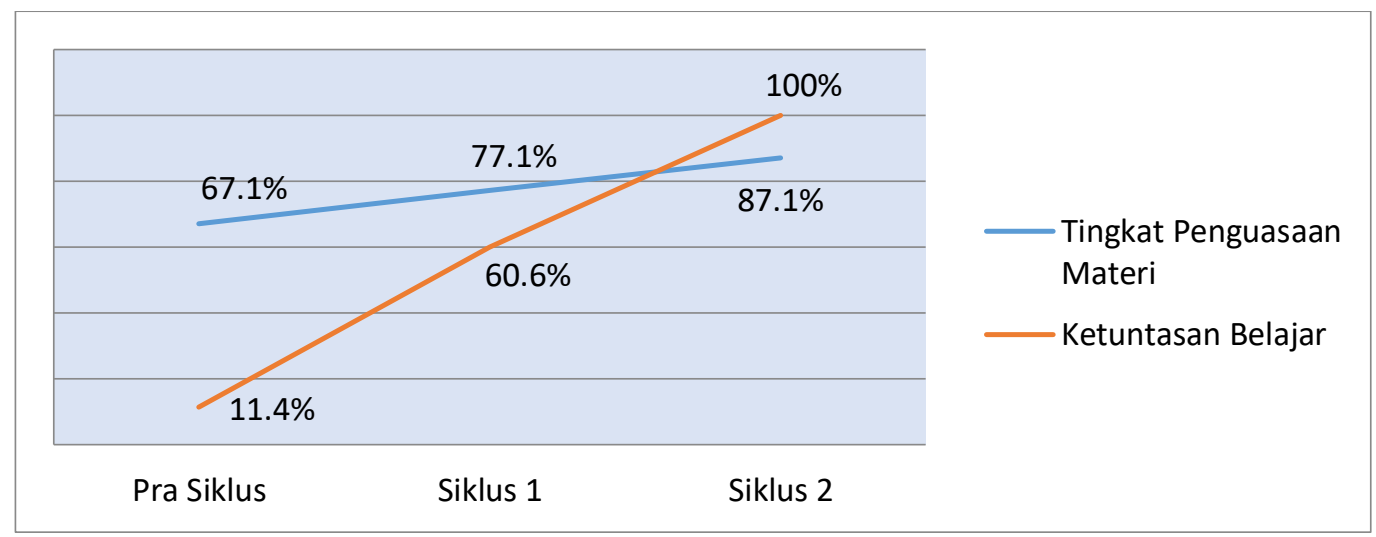

\section{Gambar 3. Histogram Hasil Analisis terhadap Nilai Tes}

Dari Tabel 3, peneliti melihat adanya peningkatan dalam persentase penguasaan materi (nilai rata-rata). Pada tindakan pra siklus penguasaan materi adalah 67.1\%. Di akhir siklus 2, jumlah ini meningkat menjadi $87.1 \%$. Ini berarti bahwa total peningkatan pada persentase penguasaan materi adalah sebesar $20 \%$.

Sedangkan ketuntasan belajar, pada tindakan pra siklus persentasenya adalah $11.4 \%$. Pada siklus 2, jumlahnya meningkat menjadi $100 \%$. Peneliti menghitung peningkatan persentase ketuntasan belajar adalah sebesar $88.6 \%$. Ini berarti bahwa indikator keberhasilan untuk kemampuan siswa telah tercapai.

Dari data-data penelitian ini dapat disimpulkan bahwa hipotesis yang menyatakan "Strategi ekspositori dapat meningkatkan pengetahuan siswa kelas XII IPA 6 SMA Negeri 1 Kawali tahun pelajaran 2018/2019 tentang peluang kejadian majemuk" dapat diterima. Jadi, kesimpulannya adalah strategi ekspositori dapat meningkatkan pengetahuan siswa kelas XII IPA 6 SMA Negeri 1 Kawali tahun pelajaran 2018/2019 tentang peluang kejadian majemuk.

Penerapan strategi ekspositori dalam pembelajaran tentang peluang kejadian majemuk di kelas XII IPA 6 menekankan pada proses penyampaian materi secara verbal dari guru pada siswa dengan maksud agar siswa XII IPA 6 dapat menguasai materi peluang kejadian majemuk secara optimal. Dengan strategi ekspositori, guru mengajar keseluruhan konsep, fakta dan aturan-aturan terkait peluang kejadian majemuk kepada siswa kelas XII IPA 6, sedangkan siswa kelas XII IPA 6 mendengarkan dan bertanya apabila tidak mengerti yang telah diterangkan oleh peneliti (Sanjaya, 2006).

Kontribusi strategi ekspositori dalam pembelajaran tentang peluang kejadian majemuk terbukti membantu peneliti pada penjelasan, penafsiran dan memudahkan siswa kelas XII IPA 6 dalam 
berbagai kesulitan dalam memahami peluang kejadian majemuk. Pelaksanaan strategi ekspositori dalam pembelajaran tentang peluang kejadian majemuk di kelas XII IPA 6 terbukti mendiagnosis secara tepat situasi pembelajaran, menciptakan pembelajaran efektif, memotivasi siswa kelas XII IPA 6 tidak hanya karena nilai atau motivasi eksternal, membuat siswa kelas XII IPA 6 tetap tekun dalam tugas sehingga tugas itu terselesaikan, dan membuat siswa kelas XII IPA 6 belajar secara efektif dan memiliki motivasi abadi untuk belajar (Trianto, 2007). Selain itu, strategi ekspositori memberikan sejumlah pengetahuan sosial, nilai-nilai moral dan keagamaan, memberikan pengalaman belajar untuk berlatih mendengarkan, sehingga siswa kelas XII IPA 6 memperoleh informasi tentang pengetahuan, nilai dan sikap untuk dihayati dan diterapkan dalam kehidupan sehari-hari, mengembangkan kemampuan kognitif, afektif, maupun psikomotornya, dan memungkinkan pengembangan dimensi perasaan mereka (Moeslichatun, 1999).

Peneliti menyampaikan materi peluang kejadian majemuk secara verbal. Pelajaran yang disampaikan adalah data atau fakta, konsep-konsep yang harus dihafal sehingga tidak menuntut siswa kelas XII IPA 6 untuk berfikir ulang. Di akhir pembelajaran, siswa kelas XII IPA 6 dapat tentang peluang kejadian majemuk dengan benar dan dapat mengungkapkan kembali materi yang telah diuraikan oleh peneliti (Hamruni, 2009).

Dengan strategi ekspositori, peneliti dapat mengontrol urutan dan keluasan materi peluang kejadian majemuk, dengan demikian peneliti dapat mengetahui sejauh mana siswa kelas XII IPA 6 menguasainya. Dalam strategi ekpositori, selain siswa kelas XII IPA 6 dapat mendengar melalui lisan tentang materi peluang kejadian majemuk sekaligus siswa kelas XII IPA 6 dapat mengobservasi melalui percobaan dengan melakukan tugas rumah.

Kegiatan peneliti dalam memberikan sugesti positif membangkitkan kekuatan pada siswa kelas XII IPA 6 untuk menembus rintangan dalam belajar. Dengan mengemukakan tujuan pembelajaran, siswa kelas XII IPA 6 memahami apa yang harus mereka kuasai serta mau dibawa kemana mereka. Kegiatan merangsang keingintahuan siswa terhadap materi membuka file dalam otak siswa kelas XII IPA 6 sehingga materi bisa cepat ditangkap (Hamruni, 2009).

Bahasa yang digunakan oleh peneliti adalah bahasa yang komunikatif dan mudah dipahami oleh siswa kelas XII IPA 6. Peneliti tidak menyajikan materi pelajaran dengan cara membaca buku atau teks tertulis, tetapi guru menyajikan materi pelajaran secara langsung dengan bahasa sendiri dengan selalu memperhatikan tingkat perkembangan mereka. Peneliti meninggikan dan merendahkan nada suaranya. Hal ini membuat perhatian siswa kelas XII IPA 6 tetap terkontrol sehingga mereka tidak merasa bosan.

Dalam proses penyajian materi, kontak mata (eye contact) yang dilakukan oleh peneliti membuat siswa kelas XII IPA 6 tetap memperhatikan pelajaran. Melalui kontak mata yang selamanya terjaga, siswa kelas XII IPA 6 merasa dihargai oleh peneliti, juga mereka seakan-akan diajak terlibat dalam proses pembelajaran. Peneliti memandangi siswa kelas XII IPA 6 secara bergiliran, tidak membiarkan pandangan mereka tertuju pada hal-hal di luar materi pelajaran.

Dalam menggunakan joke ketika pembelajaran berlangsung, peneliti menjaga agar kelas tetap hidup dan segar. Peneliti menggunakan joke yang relevan dengan isi materi. Peneliti memunculkan joke apabila dirasakan siswa kelas XII IPA 6 sudah kehilangan konsentrasinya. Peneliti mengidentifikasi hal ini dari cara mereka duduk yang tidak tenang, cara mereka memandang atau dengan gejala-gejala perilaku tertentu, misalnya dengan memain-mainkan alat tulis, mengetuk-ngetuk meja dan lain sebagainya (Hamruni, 2009).

Langkah korelasi adalah langkah menghubungkan materi peluang kejadian majemuk dengan pengalaman siswa kelas XII IPA 6 atau dengan hal-hal lain yang memungkinkan siswa kelas XII IPA 6 dapat menangkap keterkaitannya dalam struktur pengetahuan yang telah dimilikinya. Langkah korelasi ini memberikan makna terhadap materi pelajaran yang telah dimiliki siswa kelas XII IPA 6 maupun untuk meningkatkan kualitas dan kemampuan berpikir dan kemampuan motorik mereka (Hamruni, 2009). 
Kegiatan peneliti menyimpulkan materi membuat siswa kelas XII IPA 6 mengambil intisari dari proses penyajian materi. Kesimpulan memberikan keyakinan kepada siswa kelas XII IPA 6 tentang kebenaran peluang kejadian majemuk yang baru saja mereka pelajari. Dengan demikian, siswa kelas XII IPA 6 tidak merasa ragu lagi akan penjelasan yang diberikan oleh peneliti.

Langkah aplikasi dengan memberikan tugas rumah dan memberikan tes yang sesuai dengan materi peluang kejadian majemuk adalah langkah unjuk kemampuan siswa kelas XII IPA 6 setelah mereka belajar. Melalui langkah ini guru mengumpulkan informasi tentang penguasaan dan pemahaman mereka terhadap materi (Hamruni, 2009).

\section{KESIMPULAN}

Hasil penelitian ini menyatakan bahwa strategi ekspositori dapat meningkatkan pengetahuan tentang peluang kejadian majemuk siswa kelas XII IPA 6 SMA Negeri 1 Kawali tahun pelajaran 2018/2019. Hal ini ditandai dengan adanya perubahan kinerja guru dan keterampilan belajar siswa menjadi lebih positif terhadap pembelajaran. Selain itu, adanya peningkatan dalam persentase penguasaan materi (nilai rata-rata) sebesar $20.0 \%$ dan peningkatan ketuntasan belajar sebesar 88.6\%. Selain itu, setelah mendapatkan tindakan melalui strategi ekspositori, siswa kelas XII IPA 6 lebih memiliki sugesti positif terhadap pembelajaran, memahami tujuan pembelajaran yang harus dicapai, memiliki keingintahuan terhadap materi, konsentrasi, antusias, berpikir kritis, dan bersungguh-sungguh dalam belajar.

\section{REKOMENDASI}

Peneliti sebaiknya menugaskan siswa untuk melakukan observasi melalui percobaan dengan melakukan tugas rumah dengan disertai bukti proses pelaksanaannya. Bukti proses pelaksanaan pembuatan tugas dapat berupa photo atau video dengan tujuan untuk menghindari siswa menyontek tugas temannya.

\section{UCAPAN TERIMAKASIH}

Ucapan terima kasih ditujukan kepada kepala SMA Negeri 1 Kawali yang telah mengizinkan penelitian ini dilaksanakan. Ucapan terimakasih juga ditujukan kepada siswa kelas XII IPA 6 SMA Negeri 1 Kawali tahun pelajaran 2018/2019 yang telah mendukung terhadap pelaksanaan penelitian ini.

\section{DAFTAR PUSTAKA}

Hamruni. (2009). Strategi dan Model Pembelajaran Aktif Menyenangkan. Yogyakarta: Fakultas Tarbiyah.

Moeslichatun, R. (1999). Metode Pengajaran di Taman Kanak-kanak. Jakarta: Rineka Cipta.

Sanjaya, W. (2006). Strategi Pembelajaran Berorientasi Standar Proses Pendidikan. Jakarta: Kencana Prenada Media.

Trianto. (2007). Pembelajaran Inovatif Berorientasi Konstruktivistik. Jakarta: Prestasi Pustaka. 
